\title{
The influence of leadership behaviors on employee performance in Beijing, China hotel industry
}

\author{
Liu Ran \\ Faculty of PHD Management, SEGI University, Jalan Selangor Kota Damasara, Malaysia, \\ Department of Graduation school of Business SEGI University, Jalan Selangor Kota \\ Damasara, Malaysia
}

\begin{abstract}
China has successfully held the 29th Olympic Games in Beijing. China's hotel industry also got really booming in 2008. Variety of foreign hotel brands came into the China's market. Developing of hotel industry need deluge of labors to support. However, many hotels have low service quality of employees, even there was occurring in high proportion of turnover. Result in one of the main reasons of poor employees' performance is leadership behaviors; the way of leadership behaviors may directly influence employees' performance. This study researched employees 'performance in five stars hotels in Beijing, China, through the way of collect questionnaires to obtain original data. Collecting data adapt to questionnaire method the unit of analysis by SPSS system. This research finds that between employees' performance, and leadership behaviors have significant relationship, because the positive of leadership behaviors are able to employees feels happy and satisfaction. Active leadership behaviors can help employees to enhance productivity, service quality, and even creation. In this research underlined affect the most reason of employee's performance.
\end{abstract}

Key words: Task-oriented behavior, Relation-oriented behavior, Change-oriented behavior, Employees Performance,

\section{INTRODUCTION}

As a developing country, China government always concerned development of tourism industry; facilitating tourism industry must be escalating service quality of hotel industry. Therefore, employees quality and leader's management are predominate factors of ensuring high quality of operating. With rapid growth of economy of China, which attract volume of travelers and business person coming to Beijing, Selecting a good hotel is main factor of their considering before they travel. In the hotel industry, employees' performance can direct impact on customer's satisfaction and organizational reputation. Due to the hotel operate need high quality service; the feature of service is emphasis on interaction of people in the hotel, on the process of interaction employees' performance can influence customer's feeling.
Hence, leadership behavior is a key factor, which impacts on employees' attitude, emotional, and even their competence, these factors will affect customer evaluation of the hotel. for many travelers and business people, selecting a quality hotel is their necessary contents of plan before they travelling, although there are kinds of hotel brands but most of customers are willing to one hotel where they really like, and they disinclined to change hotel, because hotel just like a temporary home for customers, they like familiarly environment even familiarly service agents, however in many situations, due to service and working attitude of employees are unable to meet customers' needs, which lead customers to change other hotel, even this situation may produce negative influence hotel's reputation. Employees' performance is directly showed in front of customers, so their behaviors play a key role in customer loyalty. Some hotel's managers are more emphasis on how to improve an internal 
environment of the hotel, such as advanced equipments and luxury decorations. Actually the managers ignored establish loyalty relationship with customers would be depends more on employees how to treating customers, which is their ultimate consideration, Importantly, employees whether can provide professional service and demonstrate their own confident appearance, which is related to the behavior of leaders. Leadership behaviors possible enhance subordinate's performance, likewise leadership behaviors also can make low subordinate's performance, when the employees suffer passive behaviors of leaders, they are extremely inefficient in their job. Since the 2008 Olympic Games held in Beijing, China has become the one most favorite tourist country in area of Asia and predominate place of business activities.

A deluge of tourists and business ma are like to visit Beijing, Mainly due to tourism industry of China consistently develop and within special features. The tourism industry boots hotel industries developing, In addition to support from tourists, China hotel industry also try to develop beyond the old motifs. Currently, the effectiveness of the hotel industry achieved successful very much depends on the advanced management ideas and professional service people, professional hotel workers are the cornerstone of hotel development, The leaders of hotel decides the development of the hotel, the leadership behaviors via task-oriented behaviors, relationship-oriented behaviors, and changeoriented behaviors to improve and cultivate professional employees, Moreover employees with expertise knowledge and competence, which can attract to more potential customers and maintain repeat customers for the hotel.

There were findings that proven employee with good performance; Most of them evaluate their leaders with good comments. This effectiveness of consequence major depends on positive leadership behaviors, if there do not have a good leader to guide and cultivate employees; you may impossibly obtain a qualified subordinate.

\section{LITERATURE REVIEWS}

Leadership is the process of having certain influence in a group and guiding the group to achieve its goals via such influence. The task-oriented behavior is main making work tasks more effectiveness, making groups and individuals more clearly know key points and requirements of each task. And provide problem solution for employees, Moreover, monitoring procedure of every task and controlling employee's performance on the processes. Hence, Task-oriented behavior Leaders who perform task behavior give close guidance and attention to their employees, this behavior would make employees with stress on their workplaces as well as limits their creativity in the work process. Even make them feeling boring and deficiency of interest in their tasks result in negative consequence. The aim of setting performance standards is task-oriented, which enable to employees to understand to their tasks of work consistent with work principles, encouraging employee to complete their tasks more effectively, however, in this way is not conductive to employee development and feel no value and significance of the work, resulting in work alienation. Relation-oriented behavior means that the leaders are willing to build good and effective conversation with their subordinates, there is good interactive between leaders and employees, effective conversation and interaction are able to guide employees achieve their goals; in addition, this method can abate faults in the process of work. Relation-oriented behavior of leaders more concerned their employees' personal well-being and their emotions. Furthermore, the leaders like to coach their subordinate's skills and impart their more knowledge to buttress employee's development. Relation- oriented of leaders would like to motivate their subordinates to solve different obstacles with confident, which benefit to subordinate include better job adjustment, more skill learning grater self -confidence, and faster career advancement, likewise employees are also willing to make sufficient contributions and commitments for organization, which can increase the likelihood of success of organization in a rat race. Due to the development of the Chinese hotel industry is going to the global as well as latest technology applied, therefore the organization faces a continuous transformation process. The organization allocates responsibility to managers for guidance and predicts of a blueprint of organization in the future. Changeoriented behavior such as articulating callings for vision and encouraging innovative thinking within workplaces, collective learning in the team or organization

The leader experiment with the new approach for achieving goals and broke outdated ways, Actually, 
Change-oriented behavior is mix of task-oriented behavior and relation-oriented behavior, Leaders with these two behaviors belong to transformational leadership style. Leaders of transformational leadership are receptive to stimulate innovation of subordinates and make workflow of organizational more effectively. Example of communicate a clear vision of the benefits to be obtained from change. Communicating can inspire vision and commitment of employees at the workplace. Through communication to catch the essential of ideas of employees, understanding what are employees' want that seems to be critical, Change- oriented behavior depend more on buttress and motivation, and encourage employees to change, when they creativities are recognized by groups. Actually, in many actual work situations, some employees with special type of ideas which may increment of productivity and make more benefits for organizational. Those kinds of ideas are derived from their experiences of pervious workplaces or expertise; most of the leaders inspired employees to compliance with rules of workflow rather than excite potential capability of employees who are center of the organization, improving productivity and enhancing of service which is rely more on the employee's intelligence, so transformational leadership behavior is via changing to find out best work ways and pragmatic approaches.

\section{METHODOLOGY}

We conducted a study to understand what behaviors successful leaders in the hospitality industry typically use to lead employees most effectively. Therefore, this study analyzes three leadership behaviors, mainly studying the hotel industry in Beijing; Questionnaires were set up in multiple response surveys. Respondents were briefed on the study and questionnaire in advance to ensure that they clearly understood the purpose of the study and questionnaire. None of the respondents were forced to participate to ensure the accuracy of the results. Thank those who are willing to participate in the survey. Overall, 300 pieces of data were used for descriptive analysis using the social science statistical software package (SPSS)

\section{RESULT ANALYSES AND DISCUSSIONS}

The percentages of men and women in the sample were similar, at 48 percent and 52 percent, respectively. The respondents were mainly young, with $32 \%$ under 28 and $49 \%$ between 28 and 35 .Employees over the age of 35 account for $19 \%$, married employees account for $44 \%$ and single employees account for $56 \%$. As for the number of years the respondents have worked in hotels, $34 \%$ said they have worked in hotels for 1-3 years and $42 \%$ said they have worked in hotel industry of Beijing, China for more than 3 years. Nineteen percent of the respondents said they had worked in hotels for more than five years, and most of them earn between 3,000 and 4,000 Yuan a month. Data loss is inevitable because data is collected manually through questionnaires. However, the amount of data lost is very small, ranging from $1 \%$ to $3.3 \%$ per processing. This percentage is acceptable for quantitative statistical analysis, usually in the range of $15 \%$ to $20 \%$.Therefore; available data collection was used for the following descriptive analysis because the missing data did not affect the overall research analysis. According to the survey results, this study found that most of the respondents have experienced this phenomenon, when they get along with leaders, they will cause employees to slack off in work because of the leaders' behavior.

Table 1: Descriptive statistic

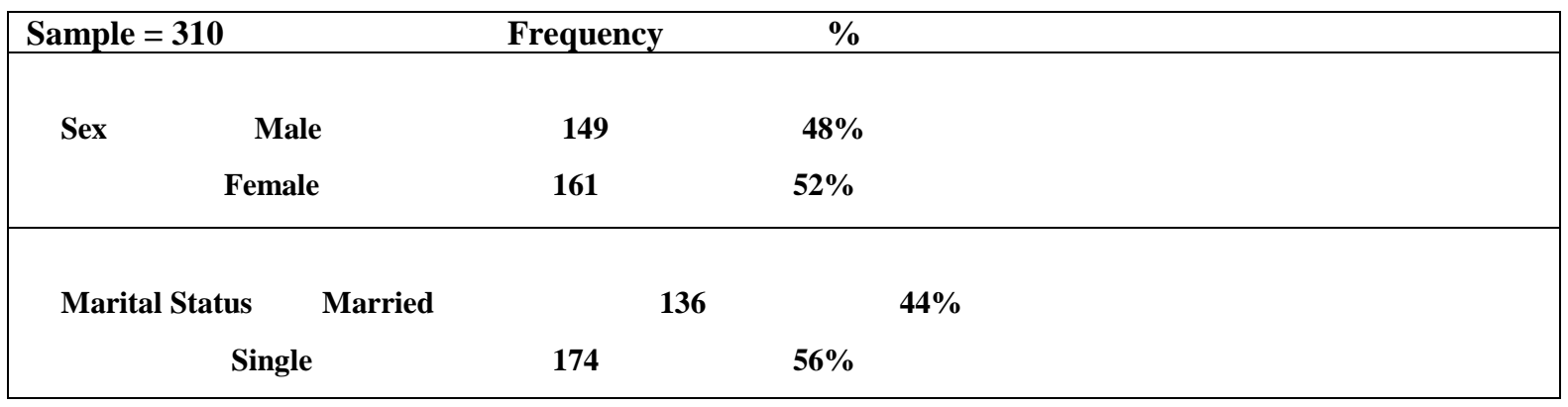




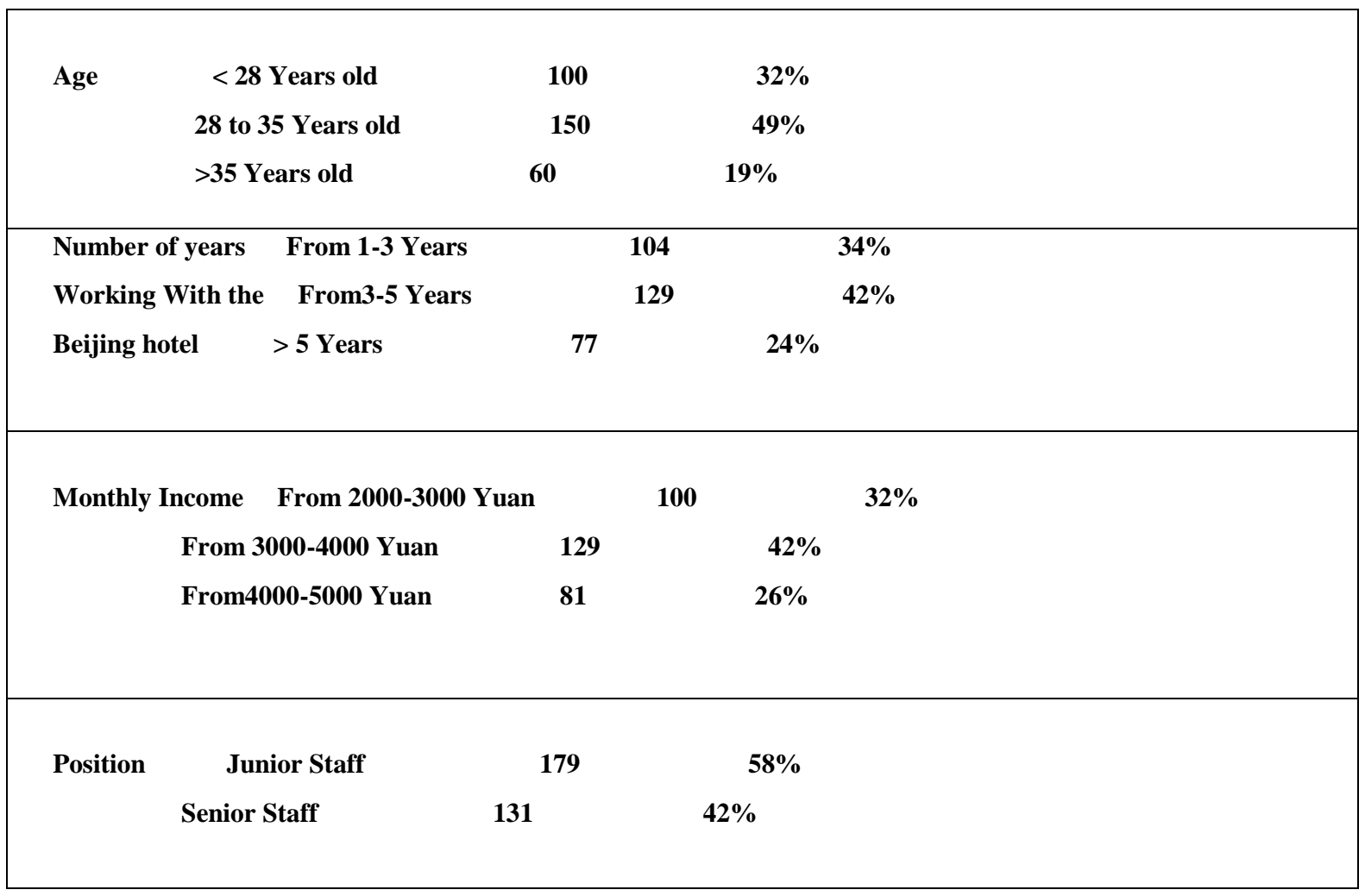

Based on the consequence of result, this study found that most of respondents convinced leadership behavior will influence their performance and even emotion in the workplaces. Accounting for $81 \%$ of the total respondents (264) Only 5\% of respondents believed that the leadership behaviors fail to impacts their working performance. $42.1 \%$ respondents believed that relation-oriented behaviors can facilitate their performance; they like to leaders provide supports on their tasks and trust subordinates can be complete very well. $53.8 \%$ of respondents convinced that change-oriented behaviors are able to upward influence their performance mixture of looking both work performance and emotions. Merely $4.1 \%$ of respondents are prone to task-oriented behaviors. Nowadays, task-oriented behaviors and relationoriented behaviors are accepted by organizations generally, task- oriented behaviors are convinced effective management approach, because these behaviors are main concentrate on criteria and consequence of work. The relation-oriented behaviors are emphasis on leaders are willing offer guides and buttress to their subordinate when employees with a difficult task. However, according to this survey delivery an information to organization. Employees are more like to changeoriented behaviors, they desire to communicate with leaders and exchange ideas to each other; they look advices forward are accepted by groups and or organization, which may better irritate their potential abilities. This study found that in organization use task-oriented behaviors, their employees think generally the work is stressful seems like a robot, task-oriented behavior maybe produce huge of productivity in short term, oppositely, if an organization conducts task-oriented behaviors with long term, which will result in employees without any interest in their job, gradually they maybe resign this job. However, change-oriented behavior is an advance concept of management and pragmatic approach, this can change employees' stereotype mindset, using way of help employees to promote productivities of employees, positive impacts employees' work attitude in this way that excite their creativity. Enhancing their confidence and assist them build a wonderful career pathway via the way of motivation. Change-oriented behaviors are pursued by majority of employees. And normally, leader's behaviors are formulated by organizations. But only top management of the hotel try to constantly change their management concepts can actual improve performance and service quality of employees, therefore, evaluating employees' performance whether qualified or unqualified is not merely measurement of they can finish them work tasks within norm time. Although compare to taskoriented behaviors, more than half of total respondents believed that relation-oriented behaviors are possible to make certain effectiveness on the process of actual management, this result prove the relation-oriented behaviors are recognized of leadership behaviors by staff and organizations. Because most of the employees are keen to get encouraging and supporting of leaders on the workplaces, 
Hence, the relation-oriented behaviors are effectively, but are not the only valid behaviors. Relation-oriented behaviors maybe more suitable for one group and organization, However, from the angle of long vision, change-oriented behaviors can better influence on all the practitioners in the hotel.

They will contribute efforts to change whole hotel industry. Employee's performance is good or bad, which depends more on the leadership behaviors. Therefore, for better promote quality service of employees and reputation of the hotel, the organization should attempt to conduct different leadership behaviors, because different behaviors will occur in different consequents. Making opportunity of learning knowledge and skills for employees and help they maintain positive attitude, these elements maybe good impact on satisfaction of customers. In addition, organizations change and involve in new leadership behaviors are reliable in changing employee performance.

\begin{tabular}{|c|c|c|c|c|c|c|}
\hline $\begin{array}{l}\text { Leadership behaviors / employees } \\
\text { performance }\end{array}$ & Very low & Low & Average & High & $\begin{array}{l}\text { Very } \\
\text { high }\end{array}$ & Total \\
\hline \multicolumn{7}{|l|}{ Task- oriented behaviors } \\
\hline Monitor operations and performance & $\begin{array}{l}94 \\
30 \%\end{array}$ & $\begin{array}{l}100 \\
32 \%\end{array}$ & $\begin{array}{l}60 \\
19 \%\end{array}$ & $\begin{array}{l}29 \\
9 \%\end{array}$ & $\begin{array}{l}27 \\
8 \%\end{array}$ & $\begin{array}{l}310 \\
98 \%\end{array}$ \\
\hline Repeat rules, polices, and standards & $\begin{array}{l}77 \\
25 \%\end{array}$ & $\begin{array}{l}76 \\
24.7 \%\end{array}$ & $\begin{array}{l}70 \\
22 \%\end{array}$ & $\begin{array}{l}46 \\
15 \%\end{array}$ & $\begin{array}{l}33 \\
11 \%\end{array}$ & $\begin{array}{l}305 \\
97.7 \%\end{array}$ \\
\hline Emphasis on consequence of tasks & $\begin{array}{l}72 \\
23 \%\end{array}$ & $\begin{array}{l}78 \\
26 \%\end{array}$ & $\begin{array}{l}69 \\
19 \%\end{array}$ & $\begin{array}{l}60 \\
18 \%\end{array}$ & $\begin{array}{l}37 \\
12 \%\end{array}$ & $\begin{array}{l}302 \\
98 \%\end{array}$ \\
\hline \multicolumn{7}{|l|}{ Relation-oriented behaviors } \\
\hline Provide coaching at the workplaces & $\begin{array}{l}10 \\
3 \%\end{array}$ & $\begin{array}{l}20 \\
6 \%\end{array}$ & $\begin{array}{l}77 \\
25 \%\end{array}$ & $\begin{array}{l}98 \\
32 \%\end{array}$ & $\begin{array}{l}99 \\
32 \%\end{array}$ & $\begin{array}{l}304 \\
98 \%\end{array}$ \\
\hline $\begin{array}{l}\text { Encourage people to determine the best } \\
\text { way to do task }\end{array}$ & $\begin{array}{l}10 \\
3 \%\end{array}$ & $\begin{array}{l}20 \\
6 \%\end{array}$ & $\begin{array}{l}77 \\
25 \%\end{array}$ & $\begin{array}{l}98 \\
32 \%\end{array}$ & $\begin{array}{l}100 \\
32 \%\end{array}$ & $\begin{array}{l}305 \\
98 \%\end{array}$ \\
\hline $\begin{array}{l}\text { Socialize with employees to build good } \\
\text { relationship }\end{array}$ & $\begin{array}{l}10 \\
3 \%\end{array}$ & $\begin{array}{l}20 \\
6 \%\end{array}$ & $\begin{array}{l}77 \\
25 \%\end{array}$ & $\begin{array}{l}98 \\
32 \%\end{array}$ & $\begin{array}{l}99 \\
32 \%\end{array}$ & $\begin{array}{l}304 \\
98 \%\end{array}$ \\
\hline \multicolumn{7}{|l|}{ Change- oriented behaviors } \\
\hline $\begin{array}{l}\text { Motivate and facilitate innovation of } \\
\text { employees }\end{array}$ & $\begin{array}{l}8 \\
2 \%\end{array}$ & $\begin{array}{l}10 \\
3 \%\end{array}$ & $\begin{array}{l}81 \\
27 \%\end{array}$ & $\begin{array}{l}100 \\
33 \%\end{array}$ & $\begin{array}{l}101 \\
33 \%\end{array}$ & $\begin{array}{l}300 \\
98 \%\end{array}$ \\
\hline $\begin{array}{l}\text { Experiment with new ideas for achieving } \\
\text { goals }\end{array}$ & $\begin{array}{l}10 \\
3 \%\end{array}$ & $\begin{array}{l}20 \\
6 \%\end{array}$ & $\begin{array}{l}77 \\
25 \%\end{array}$ & $\begin{array}{l}98 \\
32 \%\end{array}$ & $\begin{array}{l}99 \\
32 \%\end{array}$ & $\begin{array}{l}304 \\
98 \%\end{array}$ \\
\hline $\begin{array}{l}\text { Encourage employee to solve problems in } \\
\text { different ways }\end{array}$ & $\begin{array}{l}9 \\
2 \%\end{array}$ & $\begin{array}{l}15 \\
4 \%\end{array}$ & $\begin{array}{l}79 \\
25 \%\end{array}$ & $\begin{array}{l}102 \\
33 \%\end{array}$ & $\begin{array}{l}100 \\
33 \%\end{array}$ & $\begin{array}{l}305 \\
97 \%\end{array}$ \\
\hline
\end{tabular}




\section{CONCLUSION}

Although the number of hotels in Beijing, China has soared compared with before, but there is the gap between quality of service and demands of customers, hotel should be constantly improved, and employees are pillars of the hotel, enhancing their performance can really upward development of entire hotel industry. Employees of the hotel who are fond of change-oriented behaviors, these behaviors would positively influence on employees performance. Employees are led by change-oriented behaviors, they are willing to pay more efforts and fulfill commitment, and the organizational culture would exert upward guidance on them. Changeoriented behaviors are need more and more leaders to attempt it, it's only when leadership changes that followers are likely to change, inherent task-oriented behaviors mere has a short-term effect on employees performance, this way maybe finite innovation capability of employees and reduce interest on their job. In this highly competitive era, in addition to rely on high-tech; Cultivating creative employees is even more valuable Employee is a key element of competition of organization; hence task-oriented behaviors are not suitable for development of longterm goal of the organization. Relation-oriented behaviors are worth developing; these approaches are used by some leaders, mainly via building a good relationship with employees, and encourage them when they meet difficulties, this behavior can narrow distance between employees and leaders, improving employees' loyalty, some leaders think their position more higher than employees do not need to establish the relationship with subordinates, this kind of management of the concept is wrong, when the conception of the leader not on the right way, Their leadership behavior is bound to be wrong, therefore, the organization should carry out positive leadership behaviors would really change employees' performance, boosting their sense of belongings and sense of duty. Decrease turnover of employees and improve quality of service.

\section{REFERENCES}

[1] Briscoe, J.P., Hall, D.T. and DeMuth, R.L.F. (2006) Protean and Boundaryless Careers: An Empirical Exploration.

Journal of Vocational Behavior, 69, 30-47. http://dx.doi.org/10.1016/j.jvb.2005.09.003

[2] Rousseau, D.M. (1989) Psychological and Implied Contracts in Organizations. Employee Responsibilities and Rights

Journal,

2 ,

121-139.
[3] Banai, M., Reisel, W.D. and Probst, T.M. (2004)

A Managerial and Personal Control Model: Predictions of Work

Alienation and Organizational Commitment in Hungary. Journal of International Management, 10, 375-392.

http://dx.doi.org/10.1016/j.intman.2004.05.002

[4] Nair, N. and Vohra, N. (2010) An Exploration of Factors Predicting

[5] Kanungo, R.N. (1982) Measurement of Job and Work Involvement. Journal of Applied Psychology, 67, 341-349.

http://dx.doi.org/10.1037/0021-9010.67.3.341

[6] Rauch, C.F. and Behling, O. (1984) Functionalism: ers and Managers: International Perspectives on Managerial Behavior and Leadership, 45-62.

[7] S.H. Amirul, and H.N. Daud, A study on the relationship between leadership styles

and leadership effectiveness in Malaysian GLCs, European journal of business and management, 4 (8), (2012), 193-201.

[8] B.J. Avolio, Full Leadership development: Building the vital forces in organizations, Thousand Oaks, CA: Sage, 1999.

[9] B.M. Bass, and B.J. Avolio, Multifactor leadership questionnaire: third edition manual and sampler set, Menlo Park, CA: Mind Garden. Inc, 2004.

[10] B.M. Bass, Leadership and Performance beyond Expectations,

[11] Argote, L., \& Ingram, P. (2000). Knowledge transfer: A basis for

competitive advantage in firms. Organizational behavior and human

decision processes, 82(1), 150-169.

[12] Bennis, W., \& Nanus, B. (1985). Organizational learning: the management of the collective self. New Management, 3(1), 6-13. [13] Bettencourt, L. A. (2004). Change-oriented organizational citizenship

behaviors: the direct and moderating influence of goal orientation.

[14] Burke, C. S., Stagl, K. C., Klein, C., Goodwin, G. F., Salas, E., \& Halpin, S.

M. (2006). What type of leadership behaviors are functional in teams

[15] Detert, J. R., \& Trevino, L. K. (2010). Speaking up to higher-ups: How

supervisors and skip-level leaders influence employee voice. Organization

Science, 21(1), 249-270.

[16] Dooley, R. S., \& Fryxell, G. E. (1999). Attaining decision quality and

commitment from dissent: The moderating effects of loyalty and competence

in strategic decision-making teams. Academy of Management journal, 42(4),

[17] Edmondson, A. C. (2003). Speaking up in the operating room: How team 
leaders promote learning in interdisciplinary action teams. Journal of management studies, 40(6), 1419-1452.

[18] Edmondson, A. C. (2003). Speaking up in the operating room: How team

leaders promote learning in interdisciplinary action teams. Journal of management studies,

[19] Fuller, B., \& Marler, L. E. (2009). Change driven by nature: A meta-analytic

review of the proactive personality literature. Journal of Vocational Behavior,75(3), 329-345.

[20] Grant, A. M., Gino, F., \& Hofmann, D. A. (2011). Reversing the extraverted

leadership advantage:

[21] House, R. J., \& Rizzo, J. R. (1972). Role conflict and ambiguity as critical

variables in a model of organizational behavior. Organizational behavior

and human performance,

[22] Jaques, E., Clement, S. D., Rigby, C., \& Jacobs, T. O. (1986). Senior

leadership performance

[23] Nemeth, C. J. (1997). Managing innovation: When less is more. California

Management Review, 40, 59-74.

[24] Ryan, K. D., \& Oestrich, D. K. (1998). Driving fear out of the workspace.

[25] Trice, H. M., \& Beyer, J. M. (1993). The cultures of work organizations.

Prentice-Hall, 